surveys have been even more than usually reticent about their preliminary findings. For a time, plans were afort to buy or hire a Vexco drilling rig, but when these had to be abondoned for lack of hard currency, the shut-down of information was total.

Petrobaltyk's own self-produced rig, capable of operating in up to $90 \mathrm{~m}$ of water, is now moored at Gransk, waiting to go into operation. A few weeks ago, the Helsinki Convention on the Protection of the Marine Environment of the Baltic Sea Area finally became law, binding on all states of the Baltic littoral. A major point of the convention is the prohibition of oil dumping and an appeal to the contracting parties to take measures to prevent pollution resulting from the exploration and exploitation of the sea-bed and its subsoil.

Rather surprisingly, although the Soviet media paid special attention to the Baltic republics and sea in their routine annual coverage of "environment day" (June 5), the emphasis was on effluent dumping, the need for on-shore purification installations, ecology courses in universities, and the necessity for international ecology film festivals.

No mention was made of Petrobaltyk, or of what measures it proposes to take in the case of oil leakage. This may, of course, simply reflect well-placed confidence on the part of the planners. The Finns of the Asland Islands, who caught the main brunt of an oil-slick from the Gulf of Riga last year, have however expressed considerable concern; while on the south-east Baltic coast-line, the citizens of the contracting states of Petrobaityk, though less vocal, are known to feel a similar concern.

Vera Rich

\section{London Zoo}

\section{More falling-out}

THE London Zoo has run into another spot of bother. Earlier this week, it became known that Mr Michael Hanson, the newly appointed director of administration at the Zoological Society of London, had resigned his post and would be leaving on 14 August.

$\mathrm{Mr}$ Hanson, whose responsibilities include the management of the establishment and the finances of the Zoo, was recruited from the British Civil Service in September 1979. It has been apparent for some time that the chief task of the administrative director is somehow to bring back to balance the Zoo's trading account, either by making sure that enough small children ride enough elephants at a sufficient price to keep all the animals (and their keepers) fed and housed or by some other means.

There is every reason to accept the statement put out by the Zoo earlier this week that $\mathrm{Mr}$ Hanson's resignation is unconnected with that of Dr Ronald

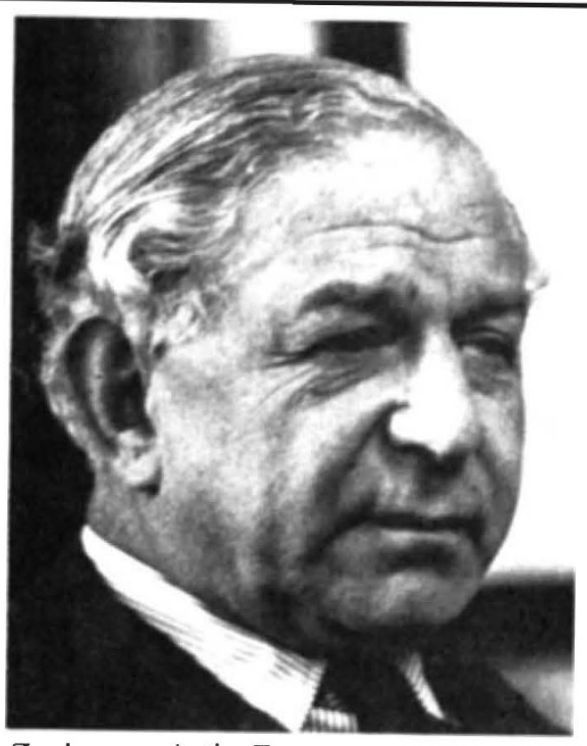

Zuckerman is the Zoo

Hedley, the part-time Secretary of the Zoo. Hedley, now Director of the British Museum (Natural History) is said to have been murmuring about overwork for several months.

The joint departure may however provide a chance for making a substantial appointment. The top establishment includes three directors (the other two responsible for animals and research), a secretary and a president, now Lord Zuckerman. Lord Zuckerman, by temperament and inclination, functions very much as an executive president - one council member said this week that 'Solly is the Zoo'.

Concern that he could not get on with the job for which he was hired without detailed scrutiny from above appears to have been one cause of Mr Hanson's departure. Recent meetings of the council have also dwelt on Mr Hanson's plans for reorganisation, considered to have been imaginative and yet similar in their essentials to plans out forward earlier.

When Mr Hanson first tendered his resignation, he was apparently asked by the council to reconsider it, but declined to do so. It is not known what may have passed between him and Lord Zuckerman.

\section{Patent law}

\section{Bugs protected}

BY the narrowest of margins, the US Supreme Court had decided that living micro-organisms can be patented. In a verdict announced on Monday, the court ruled by five to four that there is nothing inherent in existing US patent law which prevents an invention from being patented just because it is alive. The court had been asked to decide on an appeal by the Patent and Trademarks Office against the decision of a lower court to grant a patent to Dr. Ananda M. Chakrabarty of the
General Electric Company for an artificially bred strain of the bacterium Pseudomonas, first developed to help clear up oil spills by degrading different chemical components.

Dr Chakrabarty's bacterium was not created with the use of recombinant DNA techniques. However it does fall within the general category of genetic engineering and the court's verdict is seen as a welcome boost by pharmaceutical and other biotechnology companies which, together with several US university research groups, have had patent decisions on new microorganisms held up until the Supreme Court's verdict was known.

The patent application had been rejected twice by the Patent Office, largely on the grounds that, in writing the original patent laws in the eighteenth century and in discussing their subsequent revisions, Congress had at no time indicated that living organisms were explicity included.

Wide-ranging arguments had been brought in by both sides. Those supporting the patent application argued that it should be granted because of the economic importance of micro-organisms as part of the explosion of interest in biotechnology; opponents claimed that it would legitimize interference with natural processes in general, and should also be treated with particular care because of the potential health hazards.

In the end, however, the court's ruling was based on a narrow interpretation of congressional intent in writing the patent laws. Chief Justice Warren Burger, with four of his colleagues, argued that just because living matter was not mentioned in the patent laws, this did not mean it was excluded; the minority, led by Justice Brennan, argued conversely that, because of this very ambiguity, the issue of patentability should be decided by Congress rather than the courts.

Central to the case were the implications of a special law passed by Congress in 1930 allowing for the patenting of asexually reproduced plants, with an additional act in 1970 extending protection to new plant varicties capable of sexual reproduction.

The US Patent Office had argued that, unless Congress had intended the original act to exclude living matter, this additional legislation should not have been necessary. The minority agreed.

Chief Justice Burger, however, invoked the argument of Thomas Jefferson - the original author of US patent legislation that "ingenuity should receive a liberal encouragement" to confirm that a novel micro-organism can legitimately be considered as a 'manufacture' or 'composition of matter' under the terms of the Patent Acl of 1793

The Supreme Court's decision, which finally ends almost eight years of legal debate, brings the US in line with several European countries, such as the UK, which already allow living organisms to bc patented. 